\title{
Pengembangan Sistem Informasi Penerimaan Peserta Didik Baru Berbasis Web Di Smk Al- Halim Garut
}

\author{
Risma Illa Alaih ${ }^{\# 1}$, Dian Rahadian ${ }^{\# 2}$, Kuntum An Nisa Imania ${ }^{\# 3}$ \\ Program Studi Pendidikan Teknologi Informasi, Fakultas Ilmu Terapan dan Sains, Institut Pendidikan Indonesia \\ Jl. Terusan Pahlawan No.32, Kec. Tarogong Kidul, Kabupaten Garut, Jawa Barat.$$
\frac{{ }^{2} \text { dianrahadiandinstitutpendidikan.ac.id }}{{ }^{1} \text { kuntum27@intitutpendidikan.ac.id }}
$$

\begin{abstract}
Currently, the procedure for admitting new students at SMK Al-Halim Garut is considered less effective and efficient. Since the acceptance of new students is by means of prospective students who must fill out a form using the google forms provided by the school. This makes it difficult to share information with outsiders. After that, prospective students or parents must come to by the school. This makes it difficult to share information with outsiders. After that, prospective students or parents must come to
school to just see announcements or information and even submit documents related to the implementation of new student admissions. Therefore, it is necessary to develop a new web-based student information system at SMK Al-Halim Garut which can solve the problems so far. This development stage used the System Development Life Cycle (SDLC) method with the waterfall model and the need for a Unified Modeling Language (UML) which functions to make it easier to describe the system already made. The results showed that the Web-based Information System for New Student Admissions with PHP and SQL was able to manage the implementation of the New Student Admissions, such as registration, selection, announcement, and re-registration. In the feasibility test using a black box, it showed that this software was very feasible in terms of functionality.
\end{abstract}

Keywords : acceptance of new students, information system, Unified Modeling Language (UML).

Abstrak - Saat ini prosedur penerimaan peserta didik baru di SMK Al-Halim Garut dinilai kurang efektif dan efisian. Karena penerimaan peserta didik baru dengan cara calon siswa harus mengisi lembaran formulir menggunakan google form yang sudah disediakan oleh pihak sekolah. Hal ini mengakibatkan sulitnya berbagi informasi dengan pihak luar. Setelah itu calon siswa ataupun orang tua siswa harus bersusah payah mendatangi sekolah untuk sekedar melihat pengumuman atau informasi dan bahkan mnyerahkan dokumen persyaratan yang berkaitan dengan pelaksanaan penerimaan peserta didik baru. Oleh sebab itu perlu adanya suatu pengembangan sistem informasi peserta didik baru berbasis web di SMK Al-Halim Garut yang bisa dengan model waterfall dan perlu adanya Unified Modeling Language (UML) yang berfungsi untuk mempermudah menggambarkan sistem yang akan dibuat. Hasil penelitian menunjukkan bahwa Sistem Informasi Penerimaan Peserta Didik Baru Berbasis Web dengan PHP dan SQL ini mampu mengelola pelaksanaan Penerimaan Peserta Didik Baru yaitu pendaftaran, seleksi, pengumuman, dan pendaftaran ulang. Pada uji kelayakan yang mengggunakan black box menunjukkan bahwa perangkat lunak ini sangat layak dari aspek fungsional.

Kata Kunci : penerimaan peserta didik baru, sistem infromasi, Unified Modeling Language (UML).

\section{Pendahuluan}

Kemajuan teknologi informasi dan komunikasi seperti teknologi internet dan web yang saat ini mendukung proses input dan output data secara cepat dan akurat. Dari perkembangan teknologi yang demikian pesat berdampak bagi seluruh kehidupan khususnya penyedian informasi bagi suatu organisasi/instansi atau perusahaan yang membutuhkan sistem pengelolaan data secara cepat, tepat dan akurat. Untuk menunjung efektifitas, produktifitas dan efisiensi dalam suatu organisasi/instansi atau perusahaan dalam menyelesaikan masalah manajemen, terutama memberikan pelayanan kepada calon siswa baru SMK Al-Halim Garut, maka perlu menyusun suatu sistem pengelolaan data terkomputerisasi yang baik dan daya berguna. Sistem tersebut diharapkan dapat menyelesaikan tugas-tugas rutin yang berguna dalam pengambilan keputusan oleh organisasi/instansi atau perusahaan tersebut terutama dalam penerimaan peserta didik baru di SMK Al-Halim Garut.

Penerimaan Peserta Didik Baru (PPDB) merupakan program kegiatan rutin tahunan yang diadakan di sekolah. Tujuan dari proses penerimaan peserta didik baru ini adalah untuk mencari bibit-bibit unggul siswa dengan melakukan proses seleksi calon siswa baru dengan kriteria-kriteria tertentu yang ditetapkan oleh sekolah. Program penerimaan siswa baru dilaksanakan sebelum proses Kegiatan Belaja Mengajar (KBM) berlangsung. Disisi lain, sekolah yang merupakan instansi pemerintah yang bergerak di dunia pendidikan saling berlomba untuk mendapatkan input atau calon siswa yang unggul. Namun dalam pelaksanaan 
penerimaan peserta didik baru sering terjadi hambatan, misalnya ketidaktahuan calon siswa baru mengenai prosedur pendaftaran dan lokasinya, kesalahan penghitungan data, serta sulitnya memberikan informasi mengenai hasil penerimaan peserta didik baru.

Proses penerimaan peserta didik baru dimulai dengan pendaftaran, penyeleksian dan pengumuman merupakan langkah-langkah yang ditempuh untuk mengumpulkan data pendaftaran secara sistematis dalam upaya memperlancar program rutin tahunan sekolah, yaitu penerimaan penerimaan peserta didik baru. Hal tersebut merupakan kegiatan yang bertujuan untuk menjaring siswa yang sesuai dengan kriteria sekolah mulai dari segi akademik maupun non-akademik.

Pada kenyataannya, program penerimaan penerimaan peserta didik baru disekolah-sekolah yang dimulai dengan proses pendaftaran, penyeleksian dan pengumuman tersebut memang sudah secara online namun dalam langkah-langkah yang ditempuh ada beberapa yang memang dilaksanakan secara manual, artinya dalam proses pemasukan, pengolahan, hingga penyaluran data atau informasi belum menggunakan komputerisasi secara maksimal. Panitia harus mengolah data setiap ada pendaftar baru. Begitu juga dalam pengumuman hasil penerimaan peserta didik baru, panitia harus mengumumkan dengan cara mencari nilai terendah kemudian mengumumkan pada papan informasi di sekolah. Di lain sisi, calon siswa harus selalu melihat perkembangan pengumuman hasil penerimaan peserta didik baru di sekolah tersebut setiap saat. Oleh karena itu, proses penerimaan peserta didik baru manual ini dinilai kurang efektif dan efisien, baik untuk panitia penerimaan siswa baru maupun untuk calon siswa baru sendiri. Hal ini dikarenakan proses pelaksanaan penerimaan peserta didik baru tersebut dapat memakan waktu dan tenaga.

Selain permasalahan diatas, penerimaan peserta didik baru di SMK Al-Halim Garut yaitu mencapai angka yang cukup besar. Melihat proses pengolahaan data mulai dari pendafatan sampai diterima membuat panitia PPDB kewalahan dengan melihat kondisi dimana jumlah calon siswa baru dan data yang harus dimasukkan menjadi kendala dalam perekapan, pencarian dan pembaharuan data.

Hal itu, bentuk sekolah di SMK Al-Halim Garut diiringi dengan pesantren sehingga yang daftar tidak dibatasi zonasi wilayah. Oleh sebab itu, para panitia PPDB SMK Al-Halim Garut selalu mengusahakan setiap proses pendaftaran dilakukan dengan baik. Salah satu upaya yang dilakukan oleh sekolah maupun panitia PPDB yaitu dengan cara membuat pendaftaran secara online yaitu melalui google form, sehingga proses pendaftaran bisa secara online.

Namun berdasarkan hasil wawancara dengan staff tata usaha dan panitia PPDB SMK Al-Halim Garut mengenai proses pendaftaran secara online dengan menggunakan google form ini sudah berlangsung satu tahun, akan tetapi kendala dalam google form ini tidak bisa mengupload persyaratan dokumen dan foto siswa. Meskipun di google docs bisa mengupload foto, akan tetapi hasil dari upload foto tersebut kurang maksimal. Sehingga saat pendaftran pada akhirnya orangtua dan calon siswa harus datang ke sekolah untuk menyerahkan dokumen yang sudah di tentukan oleh pihak sekolah.

Melihat kondisi tersebut SMK Al-Halim Garut perlu adanya solusi untuk pelaksanaan PPDB yang diharapkan lebih efisien, baik dalam hal waktu, tempat, biaya, maupun tenaga. Oleh karena itu, dengan adanya sistem berbasis web yang menggunakan aplikasi PHP dan MySQL ini, para peserta dan orang tua peserta tidak perlu bersusah payah mendatangi sekolah untuk sekedar melihat pengumuman atau informasi yang berkaitan dengan pelaksanaan PPDB Kapanpun dan di manapun mereka berada, mereka dapat melakukannya melalui komputer maupun smartphone yang terhubung dengan internet.

Kemudian untuk meningkatkan pelayanan kepada calon siswa dibutuhkan sebuah sistem yang dapat melakukan proses PPDB yang tidak dibatasi oleh tempat [1]. Sistem informasi PPDB dapat dilakukan sistem berbasis web lebih efektif dan efisien sehingga memudahkan dalam operasional pelayanan PPDB [2].

Maka dari itu, perlu suatu sistem akademik yang mampu menangai proses penerimaan peserta didik baru (PPDB) yang sesuai dengan kebutuhan sekolah. Maka peneliti memberikan solusi kepada SMK Al-Halim Garut untuk melakukan pendaftaran siswa baru secara online melalui website dan peneliti juga melakukan studi pustaka yaitu dengan cara membaca dan mempelajari buku-buku yang mendukung topik dalam penyusunan pengembangan sistem peneriamaan peserta didik baru berbasis web ini. Selain itu pencarian/browsing dibeberapa situs di internet untuk pengumpulan data-data dan informasi yang berkaitan dengan pembuatan sistem penerimaan peserta didik baru.

Sehingga aplikasi penerimaan peserta didik baru (PPDB) berbasis web ini dapat membantu pihak sekolah khususnya dalam mengurangi kehilangan data dan menyimpan data siswa otomatis di sistem penerimaan siswa baru berbasis web.

\section{Tinjuan Pustaka}

\section{A. Sistem Informasi}

Sistem informasi adalah suatu sistem di dalam suatu organisasi yang mempertemukan kebutuhan pengolahan transaksi harian, mendukung operasi, bersifat manajerial, kegiatan strategi dari suatu organisasi dan menyediakan pihak luar tertentu dengan laporan-laporan yang diperlukan [3]. Sedangkan menurut Witarto Sistem informasi merupakan sistem, yang berisi jaringan SPD (Sistem Pengolahan Data), yang dilengkapi dengan kanal-kanal komunikasi yang digunakan dalam sistem organisasi data [4]. Elemen proses dari sistem informasi antara lain mengumpulkan data mengelolah data yang tersimpan, menyebarkan informasi.

Dapat disimpulkan bahwa sistem informasi merupakan suatu sistem di dalam suatu organisasi yang berisi jaringan SPD (Sistem Pengolahan Data). Elemen proses dari sistem 
informasi antara lain dan menyediakan pihak luar tertentu dengan laporan-laporan yang diperlukan.

\section{B. Penerimaan Peserta Didik Baru}

Kegiatan rutin dari sekolah untuk melakukan penerimaan calon murid yang memenuhi syarat tertentu untuk memperoleh pendidikan pada bentuk satuan pendidikan dan mengikuti suatu jenjang pendidikan yang lebih tinggi [5]. Penerimaan peserta didik baru adalah menerima peserta didik baru dengan melakukan pendaftaran dan persyaratan yang telah di beritahukan oleh lembaga pendidikan untuk memberikan pendidikan kepada masyarakat dalam rangka memperoleh hak-hak sebagai warga negara [6]

\section{Metode Penelitian}

Pada tahapan pengembangan sistem informasi berbasis web akan menggunakan metode System Development Life Cycle (SDLC) dengan model air terjun (waterfall). Model SDLC air terjun (waterfall) sering juga disebut model sekuensial linier (sequential linier) atau alur hidup klasik (Classic life cycle) [7]. Model air terjun in menyediakan pendekatan alur hidup perangkat lunak secara sekuensial atau terurut dimulai dari analisis, desain, pengodean, pengujian dan tahapan pendukung (support).

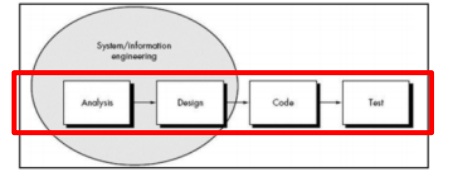

Gambar 1. Pengembangan Sistem SDLC air terjun (Waterfall) Pada gambar 1.1 menunjukn tahapan pada pengembangan sistem informasi penerimaan peserta didik baru berbasis web. Berikut ini adalah tapahan dari model waterfall.

A. Analisis

Pada tahap ini merupakan tahap awal dimana analisis dalam proses pembuatan sistem penerimaan peserta didik baru berbasis web ini menggunakan metode System Development Life Cycle (SDLC) yaitu dengan proses tahapan awal dimana menganalisa seperti pengumpulan data, analisis sistem dan identifikasi data di SMK Al-Halim Garut. Adapaun analisa yang peneliti lakukan dengan tahapan ini adalah sebagai berikut :

1. Pengumpulan Data

Pada tahapan ini peneliti melakukan pengumpulan data - data sesuai kebutuhan seperti data profile sekolah, sistem yang sudah berjalan, informasi pendaftaran, persyaratan pendaftaran dan data jadwal penyelenggaraan peserta didik baru SMK Al-Halim Garut. Peneliti memperoleh data tersebut dari pihak SMK Al-Halim Garut.

2. Analisis dan Identifikasi Data

Kemudian pada tahapan ini peneliti melakukan identifikasi kebutuhan pengguna (user) seperti calon siswa dalam melakukan pendaftaran peserta didik baru samapai calon siswa mencatak kartu peserta. Peneliti juga menganalisis kebutuhan pengguna (user) dari proses identifikasi dengan melihat kapasitas teknologi. Hal ini bertujuan dimana data tersebut berguna untuk merancang database pada pembuatan sistem PPDB.

B. Perancangan (Design)

Tahap selanjutnya setelah sudah melakukan tahapan menganalisis sitem PPDB yang sudah berjalan maka tahapan selanjutnya yaitu memberikan usulan yaitu dengan mengembangkan sistem PPDB untuk penyelesaian masalahnya. Oleh karena itu, tahap perancangan sistem PPDB yang bertujuan untuk mengatasi permasalahanpermasalahan yang ada di SMK Al-Halim Garut. Pada tahapan perancangan (design) penulis menguraikan untuk lebih jelasnya sebagai berikut :

1. Perancangan Proses Sistem

Pada tahap perancangan proses sistem peneliti menggambarkan bagaimana sistem beroperasi dan mengilustrasikan aktivitas yang dilakukan dan bagaimana data tersebut bekerja diantara aktivitasaktivitas tersebut. Upaya untuk mendapatkan spesifikasi perangkat lunak yang sesuai dengan keinginan dan kebutuhan pengguna (User), maka diperlukan komunikasi yang baik antara tim pengembangan sistem dengan pengguna sistem in nantinya. Pemodelan dalam pengembangan sistem informasi menggunakan UML. Tipe diagram UML yang akan digunakan dalam yaitu dimana pengembangan sistem informasi PPDB berbasis web ini terdiri dari Use Case Diagram, Activity Diagram dan Class Diagram hal ini untuk menggambarkan aliran proses sistem PPDB baru. Peneliti menggunakan software Microsoft Visio.

2. Perancangan Basis Data

Pada tahapan perancangan basis data peneliti melakukan pembutan data base yang terintegrasi untuk menghindari redunasi data. Peneliti menggunakan phpmyadmin dan software xampp.

3. Perancangan Antaramuka (Interface)

Pada tahapan ini peneliti melakukan proses rancang bangun sperti mebuat layout tampilan website untuk sistem informasi penerimaan peserta didik baru berbasis web di SMK Al-Halim Garut. Serta proses memasukan data ke sistem PPDB menampilan inputoutput informasi kepada user dan sebaliknya.

C. Pengkodean (Code Generation)

Pada tahapan ini sistem penulis mulai melakukan kode sistem menggunakan bahasa pemograman sesuai dengan spesifikasi yang telah diusulkan. Tahapan inilah yang merupakan tahapan secara nyata dalam mengerjakan suatu sistem.

Untuk bahasa pemograman yang digunakan adalah PHP yaitu bahasa pemograman yang sangat populer untuk membangun aplikasi berbasis web salah satungan sistem 
informasi PPDB berbasis web. Sedangkan untuk databasenya menggunakan MySql, yang merupakan software DBMS yang handal dan dapat diperoleh serta digunakan secara gratis.

D. Pengujian (Testing)

Tahapan ini melakukan pengujian diamna hanya fokus pada perangkat lunak secara dari segi lojik dan fungsional dan memastikan bahwa semua bagian sudah diuji. Hal ini dilakukan untuk meminimalisir kesalahan (error) dan memastikan keluaran yang dihasilkan sesuai yang diinginkan. Dalam penelitian ini pengujian sistem akan menggunakan pengujian Black-Box.

Pengujian black box berusaha menemukan kesalahan dalam kategori sebagai berikut [8] :

1. Fungsi-fungsi yang tidak benar atau hilang.

2. Kesalahan interface.

3. Kesalahan dalam struktur data atau akses basis data eksternal.

4. Kesalahan kinerja

5. Inisialisasi dan kesalahan terminasi.

Dari beberapa tipe pengujian yang nantinya akan di implementasikan pada sistem informasi tersebut, dapat diketahui hasil pada sebuah tabel. Diharapkan tidak ada kesalahan masukkan selama pengujian berlangsung untuk memastikan sistem menghasilkan data yang baik.

\section{HASIL DAN PEMBAHASAN}

Berikut ini adalah hasil pengembangan sistem informasi perimaan peserta didik baru berbasis web di SMK Al-Halim Garut. Hasil pengembangan akan dipaparkan sebagai berikut

A. Hasil Pengembangan Produk

1. Akses Halaman Utama

Akses halaman utama bisa di akses oleh siapa saja yang mengakses website ini, asalkan mengetahui alamat website dan mempunyai koneksi internet, halaman utama digunakan untuk sumber informasi dan pendaftaran siswa baru smk alhalim garut.

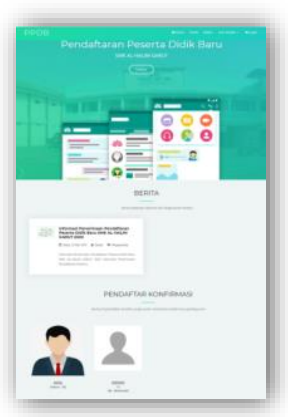

Gambar 2. Gambar Halaman Utam

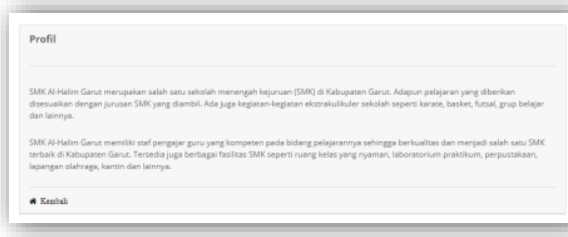

Gambar 3. Gambar Halaman Berita

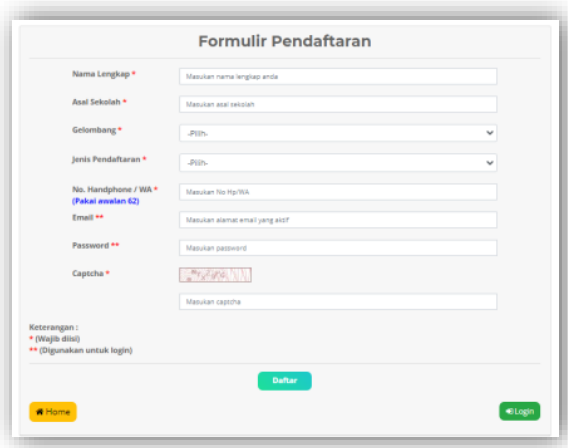

Gambar 4. Gambar Halaman Pendaftaran

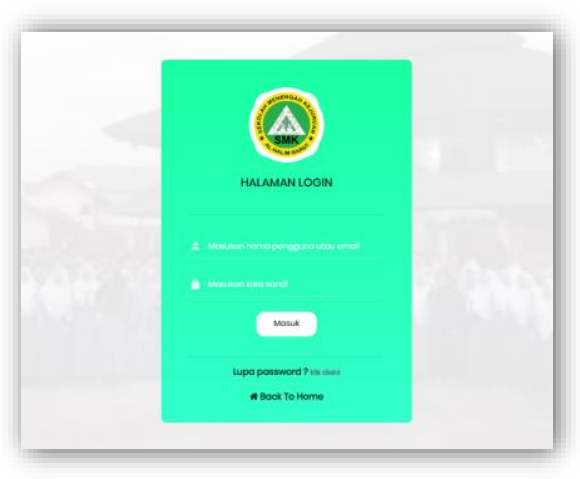

Gambar 5. Gambar Halaman Login

a. Akses Peserta

Akses pertama yang harus dilakukan oleh peserta adalah mengisi form pendfataran selanjutnya login 
p-ISSN : 2640-7363

e-ISSN : 2614-6606

menggunakan username berupa email yang di daftarkan dan password yang telah diberikan oleh sistem, setelah itu peserta mengisi data yang harus dilengkapi.

1) Halaman Utama Peserta

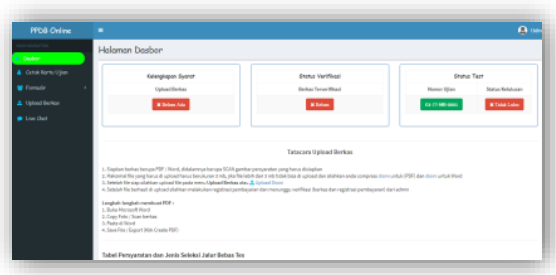

Gambar 6. Tampilan Halaman Utama Peserta

Halaman ini merupakan halaman awal saat peserta berhasil login, pada halaman ini siswa dapat melihat informasi berupa kelengkapan data dan hasil kelulusan.

2) Halaman Ceta Kartu Ujian

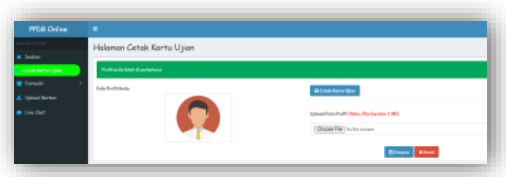

Gambar 7. Tampilan Halaman Cetak Kartu Ujian

Halaman ini merupakan halaman cetak kartu ujian dimana siswa yang akan mengikuti tes ujian bias mencetak kartu ujian nya pada halaman ini.

3) Halaman Formulir Form Utama

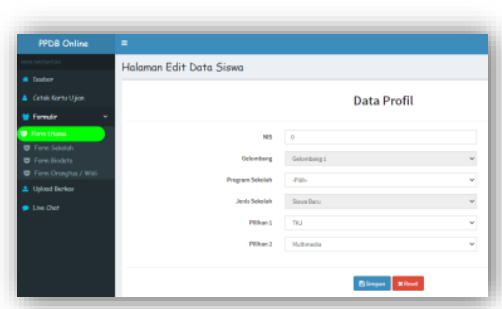

Gambar 8. Tampilan Halaman Formulir Form Utama Halaman ini merupakan halaman yang digunakan oleh peserta untuk melengkapi beberapa data yang harus dilengkapi peserta yaitu data utama.

4) Halaman Formulir Form Sekolah

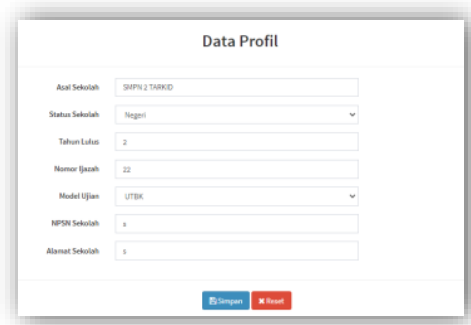

Gambar 9. Tampilan Halaman Formulir Form Sekolah

Halaman ini merupakan halaman yang digunakan oleh peserta untuk melengkapi beberapa data yang harus dilengkapi peserta yaitu data sekolah.

5) Halaman Formulir Form Biodata

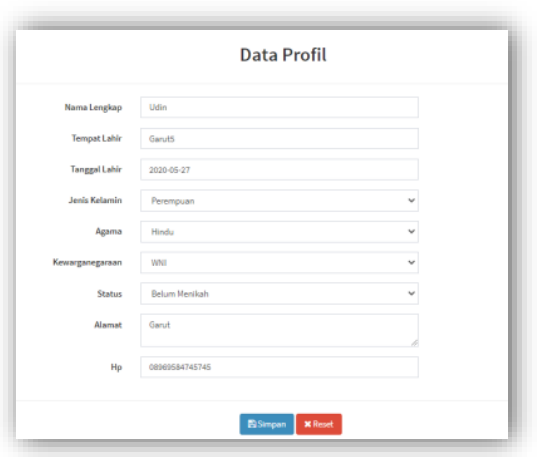

Gambar 10. Tampilan Halaman Formulir Form Biodata

Halaman ini merupakan halaman yang digunakan oleh peserta untuk melengkapi beberapa data yang harus dilengkapi peserta yaitu biodata.

6) Halaman Formulir Orangtua/Wal

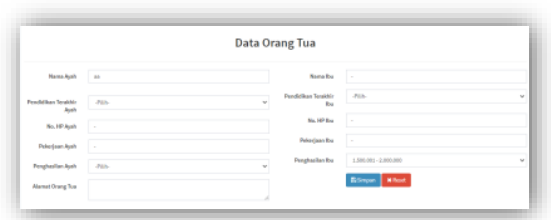

Gambar 11. Tampilan Halaman Formulir Orangtua/Wali

Halaman ini merupakan halaman yang digunakan oleh peserta untuk melengkapi beberapa data yang harus dilengkapi peserta yaitu Orangtua/Wali.

7) Halaman Upload Berkas 


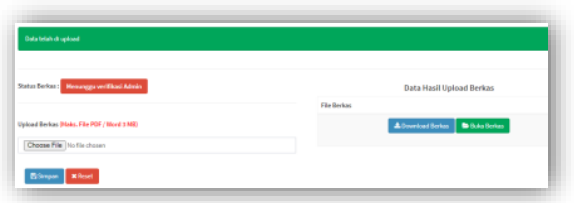

Gambar 12. Tampilan Halaman Upload Berkas

Halaman ini digunakan untuk upload berkas-berka yang harus di upload sesuai syarat yang tertera di halaman utama peserta.

8) Halaman Live Chat

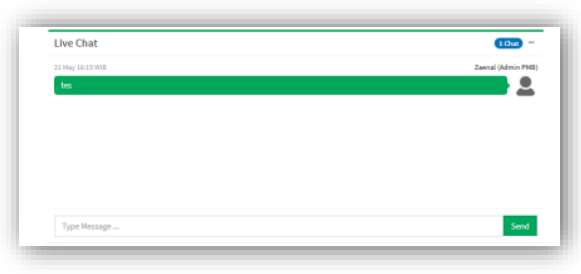

Gambar 13. Tampilan Halaman Live Chat

Halaman ini digunakan sebagai media komunikasi antaran peserta dan panitia PPDB.

2. Akses Panitian PPDB

a. Halaman Utama Panitita PPDB

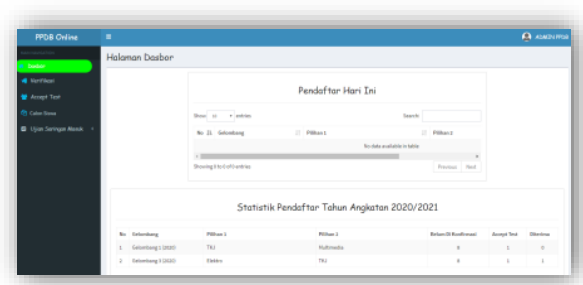

Gambar 14. Tampilan Halaman Utama Panitia PPDB Halaman ini digunakan oleh panitia PPDB untuk melihat statistik siswa baru yang telah daftar.

b. Halaman Verifikasi

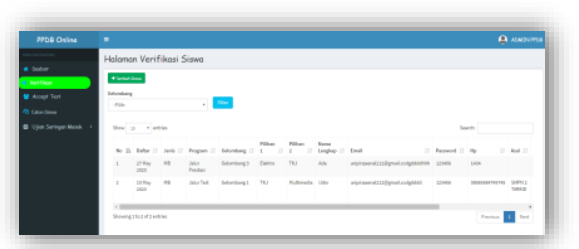

Gambar 15. Tampilan Halaman Verifikasi
Halaman ini digunakan oleh panitia PPDB dan Pengelola Website untuk memfilter data sesuai gelombang, memverfikasi data peserta, melihat kelengkapan data peserta dan membalas chat dari peserta, melihat detail data peserta.

c. Halaman Accept Test

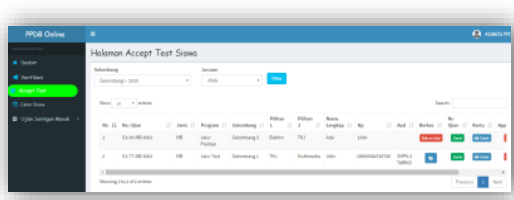

Gambar 16. Tampilan Halaman Accept Test

Halaman ini digunakan oleh panitia PPDB dan Pengelola Website untuk memfilter data sesuai gelombang dan jurusan, meluluskan peserta, mencetak kartu ujian dan formulir, mengenerate dan mengganti no ujian, melihat kelengkapan berkas dan membalas chat dari peserta.

d. Halaman Calon Siswa

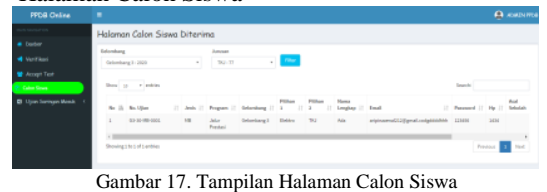

Halaman ini digunakan oleh panitia PPDB dan Pengelola Website untuk memfilter data sesuai gelombang dan jurusan, melihat data peserta yang lulus, membatalkan kelulusan dan melihat kelengkapan berkas.

e. Halaman Ujian Saringan Masuk

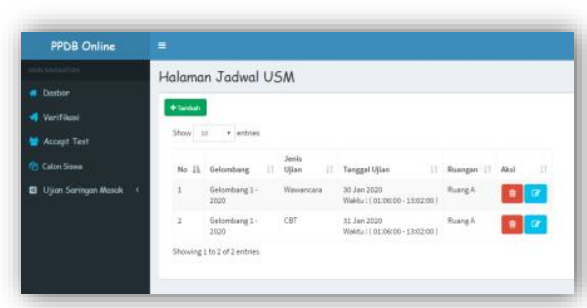

Gambar 18. Tampilan Halaman Jadwal Ujian Saringan Masuk Halaman ini digunakan oleh panitia PPDB dan Pengelola Website untuk menyiapkan jadwal ujian saringan masuk.

3. Pengelola Website

a. Halaman Utama Pengelola Website (Admin) 
p-ISSN : 2640-7363

e-ISSN : 2614-6606

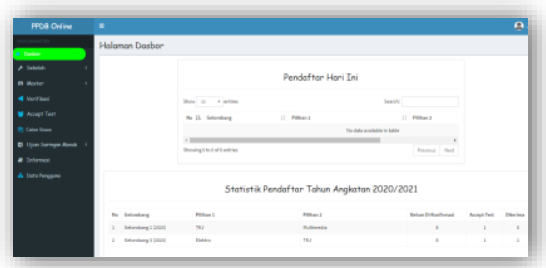

Gambar 19. Tampilan Halaman Utama Admin

Halaman ini digunakan oleh admin untuk melihat statistik siswa baru yang telah daftar.

b. Halaman Konfigurasi Sekolah

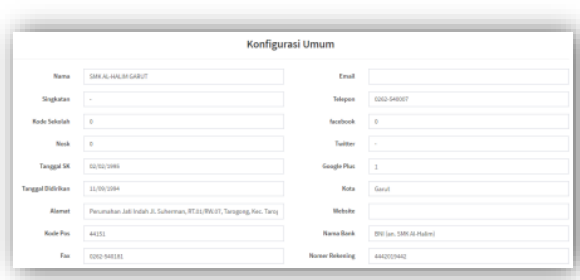

Gambar 20. Tampilan Halaman Konfigurasi Sekolah

Halaman ini digunakan admin untuk mengelola tampilan halaman awal saat web di akses peserta

c. Halaman Konfigurasi Logo

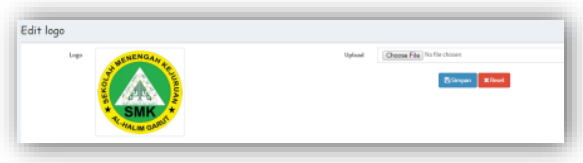

Gambar 21. Tampilan Halaman Konfigurasi Logo Halaman ini digunakan admin untuk mengganti logo dari website penerimaan peserta didik baru di SMK AlHalim Garut.

d. Halaman Konfigurasi Favicon

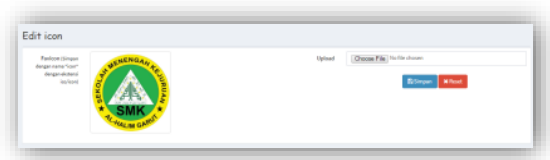

Gambar 22. Tampilan Halaman Konfigurasi Favicon Halaman ini digunakan admin untuk mengganti Favicon dari website.

e. Halaman Master Gelombang

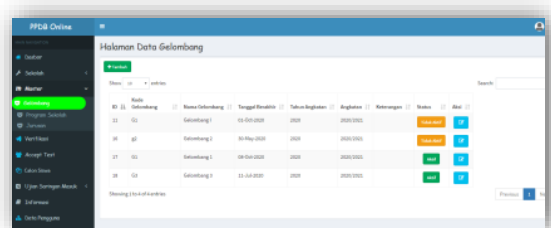

Gambar 23. Tampilan Halaman Master Gelombang

Halaman ini digunakan admin untuk mengelola gelombang pendaftaran.

f. Halaman Master Program

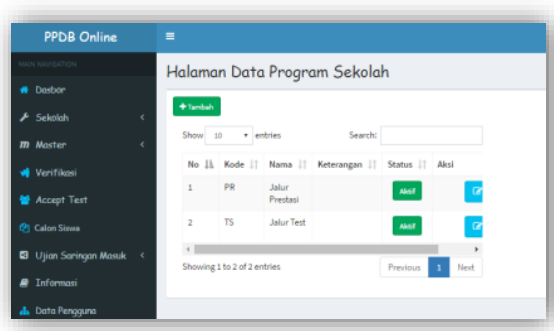

Gambar 24. Tampilan Halaman Master Program

Halaman ini digunakan admin untuk mengelola program pendaftaran.

g. Halaman Master Jurusan

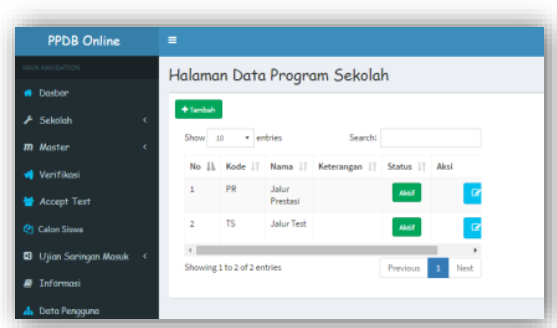

Gambar 25. Tampilan Halaman Master Jurusan

Halaman ini digunakan admin untuk mengelola jurusan sekolah.

h. Halaman Informasi 
p-ISSN : 2640-7363

e-ISSN : 2614-6606

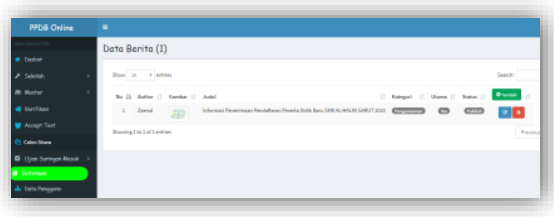

Gambar 26. Tampilan Halaman Informasi

Halaman ini digunakan admin untuk mengelola berita yang akan ditampilkan di halawan awal pada bagian berita. i. Halaman Data Pengguna

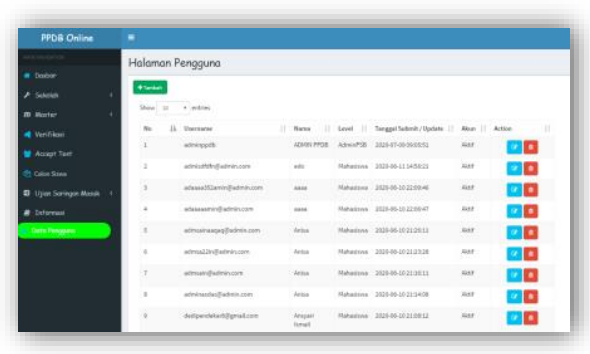

Gambar 27. Tampilan Halaman Pengguna

Halaman ini digunakan admin untuk mengelola data pengguna yang login ke sistem.

j. Halaman Verifikasi Admin

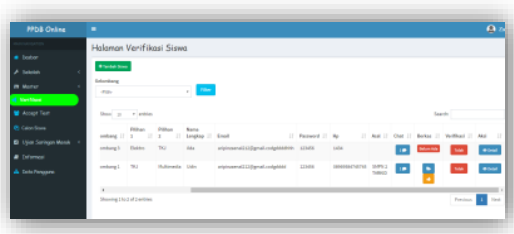

Gambar 28. Tampilan Halaman Verifikasi

Halaman ini digunakan oleh admin untuk memfilter data sesuai gelombang, memverfikasi data peserta, melihat kelengkapan data peserta dan membalas chat dari peserta, melihat detail data peserta.

k. Halaman Detail Data Peserta

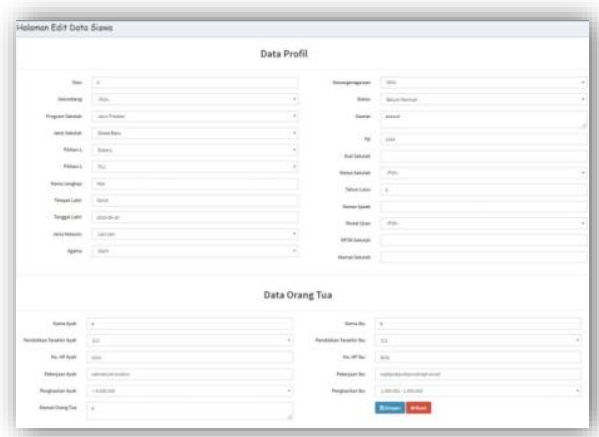

Gambar 29. Tampilan Halaman Detail Data Peserta

Halaman ini digunakan oleh admin untuk melihat detail data yang sudah dilengkapi oleh peserta.

1. Halaman Accept Test

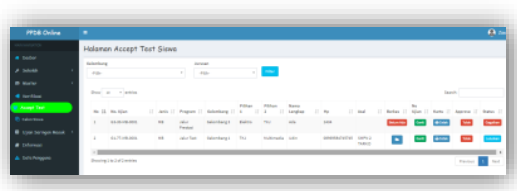

Gambar 30. Tampilan Halaman Accept Test

Halaman ini digunakan oleh admin untuk memfilter data sesuai gelombang dan jurusan, meluluskan peserta, mencetak kartu ujian dan formulir, mengenerate dan mengganti no ujian, melihat kelengkapan berkas dan membalas chat dari peserta.

m. Halaman Calon Siswa

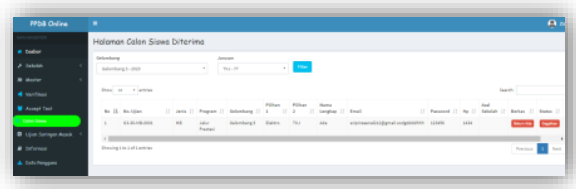

Gambar 31. Tampilan Halaman Calon Siswa

Halaman ini digunakan oleh admin untuk memfilter data sesuai gelombang dan jurusan, melihat data peserta yang lulus, membatalkan kelulusan dan melihat kelengkapan berkas.

n. Halaman Ujian Saringan Masuk 
p-ISSN : 2640-7363

e-ISSN : 2614-6606

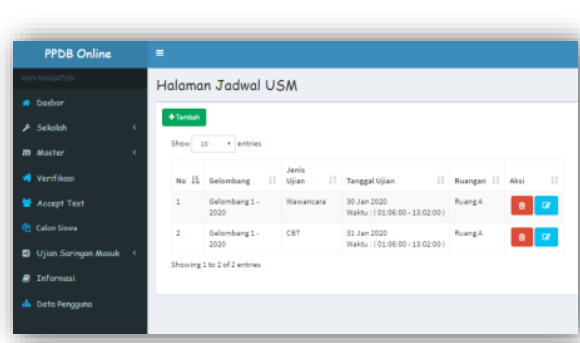

Gambar 32. Tampilan Halaman Jadwal Ujian Saringan Masuk Halaman ini digunakan oleh admin untuk menyiapkan jadwal ujian saringan masuk.

\section{B. Testing Software}

Black Box Testing adalah pengujian yang dilakukan hanya mengamati hasil eksekusi melalui data uji dan memeriksa fungsional dari perangkat lunak. Jadi dianalogikan seperti kita melihat suatu kotak hitam, kita hanya bisa melihat penampilan luarnya saja, tanpa mengetahui ada apa dibalik bungkus hitamnya. Sama seperti pengujian black box, mengevaluasi hanya dari tampilan luarnya (interface-nya), fungsionalitasnya. Tanpa mengetahui apa sesungguhnya yang terjadi didalam proses detailnya (hanya input dan outputnya). Berikut ini adalah hasil pengembangan sistem informasi penerimaan peserta didik baru (ppdb) berbasis web di smk al - halim garut menggunakan metode black box.

1. Pengujian Menu Utama

Tabel I

Tabel Pengujian Black I
\begin{tabular}{|c|l|l|l|l|}
\hline No & $\begin{array}{l}\text { Fungsi yang Menu Utama } \\
\text { di uji }\end{array}$ & $\begin{array}{l}\text { Cara } \\
\text { pengujian }\end{array}$ & $\begin{array}{l}\text { Hasil yang } \\
\text { diharapkan }\end{array}$ & $\begin{array}{c}\text { Hasil } \\
\text { pengujian }\end{array}$ \\
\hline 1. & $\begin{array}{l}\text { Menu } \\
\text { beranda } \\
\text { utama }\end{array}$ & $\begin{array}{l}\text { Pada } \\
\text { website ini } \\
\text { menampilk } \\
\text { an halaman } \\
\text { beranda } \\
\text { utama yang } \\
\text { dapat } \\
\text { digunakan } \\
\text { oleh } \\
\text { admin, } \\
\text { panitia dan } \\
\text { calon siswa }\end{array}$ & $\begin{array}{l}\text { Menampilkan } \\
\text { halaman } \\
\text { beranda }\end{array}$ & Sesuai \\
& & & \\
& & \\
\end{tabular}

\begin{tabular}{|c|c|c|c|c|}
\hline 2. & $\begin{array}{l}\text { Menu } \\
\text { Pendaf } \\
\text { taran }\end{array}$ & $\begin{array}{l}\text { Pada menu } \\
\text { ini } \\
\text { menampilk } \\
\text { an halaman } \\
\text { formulir } \\
\text { pendafaftar } \\
\text { an untuk } \\
\text { siswa baru }\end{array}$ & $\begin{array}{l}\text { Jika seluruh } \\
\text { data diisi } \\
\text { dengan benar, } \\
\text { maka data } \\
\text { tersebut akan } \\
\text { tersimpan di } \\
\text { database, dan } \\
\text { memasukan } \\
\text { username } \\
\text { berupa email } \\
\text { dan password } \\
\text { untuk login saat } \\
\text { pendaftaran } \\
\text { berhasil }\end{array}$ & Sesuai \\
\hline 3. & $\begin{array}{l}\text { Menu } \\
\text { Berita }\end{array}$ & $\begin{array}{l}\text { Pada } \\
\text { website ini } \\
\text { menampilk } \\
\text { an } \\
\text { halaman } \\
\text { berita }\end{array}$ & $\begin{array}{l}\text { Menampilkan } \\
\text { halaman berita }\end{array}$ & Sesuai \\
\hline 4. & $\begin{array}{l}\text { Menu } \\
\text { Profil }\end{array}$ & $\begin{array}{l}\text { Pada } \\
\text { website ini } \\
\text { menampilk } \\
\text { an halaman } \\
\text { profil } \\
\text { sekolah }\end{array}$ & $\begin{array}{l}\text { Menampilkan } \\
\text { halaman } \\
\text { sekolah }\end{array}$ & Sesuai \\
\hline
\end{tabular}

2. Pengujian Menu Calon Siswa Tabel II

Tabel Pengujian Black Box Menu Calon Siswa

\begin{tabular}{|l|l|l|l|l|}
\hline No & $\begin{array}{c}\text { Fungsi yang } \\
\text { di uji }\end{array}$ & Cara pengujian & $\begin{array}{l}\text { Hasil yang } \\
\text { diharapkan }\end{array}$ & $\begin{array}{c}\text { Hasil } \\
\text { pengu } \\
\text { jian }\end{array}$ \\
\hline 1. & Menu Login & $\begin{array}{l}\text { Pada menu } \\
\text { login calon } \\
\text { siswa } \\
\text { memasukan } \\
\text { username } \\
\text { berupa email } \\
\text { dan password }\end{array}$ & $\begin{array}{l}\text { Jika data sesuai } \\
\text { dengan yang di } \\
\text { daftarkan maka } \\
\text { calon siswa } \\
\text { akan berhasil } \\
\text { masuk menu } \\
\text { utama calon } \\
\text { siswa }\end{array}$ & Sesuai \\
\hline
\end{tabular}


-ISSN : 2640-7363

e-ISSN : 2614-6606

\begin{tabular}{|c|c|c|c|c|}
\hline 2. & $\begin{array}{l}\text { Menu } \\
\text { dasbor } \\
\text { Calon } \\
\text { Siswa }\end{array}$ & $\begin{array}{l}\text { Pada menu } \\
\text { dasbor calon } \\
\text { siswa ini } \\
\text { menampilka } \\
\text { n informasi } \\
\text { mengenai } \\
\text { kelengkapan } \\
\text { data, } \\
\text { verifikasi } \\
\text { berkas dan } \\
\text { kelulusan }\end{array}$ & $\begin{array}{l}\text { Jika menu } \\
\text { dasbor di klik } \\
\text { maka sistem } \\
\text { akan } \\
\text { menampilkan } \\
\text { informasi } \\
\text { mengenai } \\
\text { kelengkapan } \\
\text { data, } \\
\text { verifikasi } \\
\text { berkas dan } \\
\text { kelulusan }\end{array}$ & Sesuai \\
\hline 3. & $\begin{array}{l}\text { Menu } \\
\text { Formulir } \\
\text { Form } \\
\text { Utama }\end{array}$ & $\begin{array}{l}\text { Pada menu } \\
\text { formulir form } \\
\text { utama calon } \\
\text { siswa bisa } \\
\text { melihat data } \\
\text { yang telah } \\
\text { diisi saat } \\
\text { pendaftaran }\end{array}$ & $\begin{array}{l}\text { Jika menu } \\
\text { formulir form } \\
\text { utama di klik } \\
\text { maka data } \\
\text { yang telah } \\
\text { diisi saat } \\
\text { pendaftaran }\end{array}$ & Sesuai \\
\hline 4. & $\begin{array}{l}\text { Menu } \\
\text { Formulir } \\
\text { Form } \\
\text { Sekolah }\end{array}$ & $\begin{array}{l}\text { Pada menu } \\
\text { formulir form } \\
\text { sekolah calon } \\
\text { siswa bisa } \\
\text { melengkapi } \\
\text { data sekolah }\end{array}$ & $\begin{array}{l}\text { Jika pada } \\
\text { menu formulir } \\
\text { form sekolah } \\
\text { dilengkapi } \\
\text { maka data } \\
\text { akan } \\
\text { tersimpan ke } \\
\text { dalam } \\
\text { database }\end{array}$ & Sesuai \\
\hline 5. & $\begin{array}{l}\text { Menu } \\
\text { Formulir } \\
\text { Form } \\
\text { biodata }\end{array}$ & $\begin{array}{l}\text { Pada menu } \\
\text { formulir form } \\
\text { biodata calon } \\
\text { siswa bisa } \\
\text { melengkapi } \\
\text { biodata }\end{array}$ & $\begin{array}{l}\text { Jika pada } \\
\text { menu formulir } \\
\text { form biodata } \\
\text { dilengkapi } \\
\text { maka data } \\
\text { akan } \\
\text { tersimpan ke } \\
\text { dalam } \\
\text { database }\end{array}$ & Sesuai \\
\hline 6 & $\begin{array}{l}\text { Menu } \\
\text { cetak } \\
\text { kartu } \\
\text { ujian }\end{array}$ & $\begin{array}{l}\text { Pada menu } \\
\text { cetak kartu } \\
\text { ujian calon } \\
\text { siswa bisa } \\
\text { upload foto } \\
\text { profil untuk } \\
\text { kartu ujian } \\
\text { dan bisa } \\
\text { mencetak } \\
\text { kartu ujian }\end{array}$ & $\begin{array}{l}\text { Jika calon } \\
\text { siswa upload } \\
\text { foro profil } \\
\text { maka saat } \\
\text { mencetak } \\
\text { kartu ujian } \\
\text { akan ada foto } \\
\text { profil pada } \\
\text { kartu ujianya }\end{array}$ & Sesuai \\
\hline
\end{tabular}

\begin{tabular}{|c|c|c|c|c|}
\hline 7. & $\begin{array}{l}\text { Menu } \\
\text { upload } \\
\text { berkas }\end{array}$ & $\begin{array}{l}\text { Pada menu } \\
\text { upload berkas } \\
\text { calon siswa } \\
\text { bisa upload } \\
\text { berkas-berkas } \\
\text { yang harus } \\
\text { disiapkan } \\
\text { sebagai } \\
\text { persyaratan } \\
\text { pendaftaran }\end{array}$ & $\begin{array}{l}\text { Jika calon } \\
\text { siswa upload } \\
\text { berkas maka } \\
\text { calon siswa } \\
\text { bisa melihat } \\
\text { dan } \\
\text { mengganti } \\
\text { berkas jika } \\
\text { dalam upload } \\
\text { berkas ada } \\
\text { data yang } \\
\text { salah }\end{array}$ & Sesuai \\
\hline 8. & $\begin{array}{l}\text { Menu live } \\
\text { chat }\end{array}$ & $\begin{array}{l}\text { Pada menu } \\
\text { live chat calon } \\
\text { siswa bisa } \\
\text { menghubungi } \\
\text { admin yang } \\
\text { mengelola } \\
\text { pendaftaran } \\
\text { siswa baru }\end{array}$ & $\begin{array}{l}\text { Setelah } \\
\text { mengirimkan } \\
\text { chat ke admin } \\
\text { maka list } \\
\text { chatting } \\
\text { dengan admin } \\
\text { akan tampil } \\
\text { dan } \\
\text { bertambah }\end{array}$ & Sesuai \\
\hline 9. & $\begin{array}{l}\text { Menu } \\
\text { logout }\end{array}$ & $\begin{array}{l}\text { Pada menu } \\
\text { logout calon } \\
\text { siswa klik } \\
\text { tombol keluar } \\
\text { untuk keluar } \\
\text { dan kembali } \\
\text { ke halaman } \\
\text { login }\end{array}$ & $\begin{array}{l}\text { Setelah } \\
\text { tombol keluar } \\
\text { di klik pada } \\
\text { bagian icon } \\
\text { pojok kanan } \\
\text { maka calon } \\
\text { siswa akan } \\
\text { keluar dari } \\
\text { website dan } \\
\text { kembali ke } \\
\text { halaman login }\end{array}$ & Sesuai \\
\hline
\end{tabular}

3. Pengujian Menu Admin

Tabel III

Tabel Pengujian Black Box Menu Admin

\begin{tabular}{|c|c|c|c|c|}
\hline No & $\begin{array}{c}\text { Fungsi yang } \\
\text { di uji }\end{array}$ & Cara pengujian & $\begin{array}{l}\text { Hasil yang } \\
\text { diharapkan }\end{array}$ & $\begin{array}{c}\text { Hasil } \\
\text { penguj } \\
\text { ian }\end{array}$ \\
\hline 1. & $\begin{array}{l}\text { Menu } \\
\text { Konfig } \\
\text { urasi } \\
\text { Sekola } \\
\text { h }\end{array}$ & $\begin{array}{l}\text { Pada menu } \\
\text { konfiguras } \\
\text { i sekolah } \\
\text { ini } \\
\text { menampilk } \\
\text { an } \\
\text { digunakan } \\
\text { untuk } \\
\text { mengatur } \\
\text { sebagian } \\
\text { tampilan } \\
\text { yang akan } \\
\text { ditampilka } \\
\text { n di } \\
\text { halaman } \\
\text { utama } \\
\text { website }\end{array}$ & $\begin{array}{l}\text { Jika beberapa } \\
\text { data diubah } \\
\text { berupa nama, } \\
\text { emal, no telp } \\
\text { dsb. Maka, } \\
\text { akan } \\
\text { tersimpan di } \\
\text { database }\end{array}$ & Sesuai \\
\hline
\end{tabular}


p-ISSN : 2640-7363

e-ISSN : 2614-6606

\begin{tabular}{|c|c|c|c|c|}
\hline 2. & $\begin{array}{l}\text { Menu } \\
\text { Konfig } \\
\text { urasi } \\
\text { Logo } \\
\text { dan } \\
\text { Icon }\end{array}$ & $\begin{array}{l}\text { Pada } \\
\text { menu } \\
\text { konfigura } \\
\text { si logo } \\
\text { atau icon } \\
\text { admin } \\
\text { dapat } \\
\text { menggant } \\
\text { i logo } \\
\text { dan } \\
\text { favicon }\end{array}$ & $\begin{array}{l}\text { Setelah logo di } \\
\text { upload maka } \\
\text { logo pada } \\
\text { halaman login } \\
\text { dan kartu ujian } \\
\text { berubah, dan } \\
\text { setelah icon di } \\
\text { upload maka } \\
\text { favicon pada } \\
\text { website berubah }\end{array}$ & Sesuai \\
\hline 3. & $\begin{array}{l}\text { Menu } \\
\text { master } \\
\text { gelomba } \\
\text { ng }\end{array}$ & $\begin{array}{l}\text { Pada menu } \\
\text { master } \\
\text { gelombang } \\
\text { admin dapat } \\
\text { menambah, } \\
\text { menrubah dan } \\
\text { menghapus } \\
\text { gelombang }\end{array}$ & $\begin{array}{l}\text { Setelah } \\
\text { gelombang di } \\
\text { tambah maka } \\
\text { data akan masuk } \\
\text { database, setelah } \\
\text { di ubah maka } \\
\text { data gelombang } \\
\text { akan berubah } \\
\text { dan setelah di } \\
\text { hapus maka data } \\
\text { akan } \\
\text { menghilang dari } \\
\text { database, dan } \\
\text { juga gelombang } \\
\text { pada form } \\
\text { pendaftaran } \\
\text { akan berakhir } \\
\text { sesuai tanggal } \\
\text { yang kita } \\
\text { tentukan }\end{array}$ & Sesuai \\
\hline 4. & $\begin{array}{l}\text { Menu } \\
\text { master } \\
\text { jurusan }\end{array}$ & $\begin{array}{l}\text { Pada menu } \\
\text { master } \\
\text { jurusan admin } \\
\text { dapat } \\
\text { menambah, } \\
\text { merubah dan } \\
\text { menghapus } \\
\text { jurusan }\end{array}$ & $\begin{array}{l}\text { Setelah jurusan } \\
\text { di tambah maka } \\
\text { data akan masuk } \\
\text { database, setelah } \\
\text { diubah maka } \\
\text { data jurusan } \\
\text { akan berubah } \\
\text { dan setelah di } \\
\text { hapus maka data } \\
\text { akan } \\
\text { menghilang dari } \\
\text { database, dan } \\
\text { juga jurusan } \\
\text { yang akan } \\
\text { ditampilkan } \\
\text { pada pengisian } \\
\text { form } \\
\text { pendaftaran } \\
\text { adalah yang } \\
\text { aktif saja }\end{array}$ & Sesuai \\
\hline
\end{tabular}

\begin{tabular}{|c|c|c|c|c|}
\hline 5. & $\begin{array}{l}\text { Menu } \\
\text { master } \\
\text { program }\end{array}$ & $\begin{array}{l}\text { Pada menu } \\
\text { master } \\
\text { program } \\
\text { admin dapat } \\
\text { menambah, } \\
\text { merubah dan } \\
\text { menghapus } \\
\text { program }\end{array}$ & $\begin{array}{l}\text { Setelah program } \\
\text { di tambah maka } \\
\text { data akan masuk } \\
\text { database, setelah } \\
\text { diubah maka } \\
\text { data jurusan } \\
\text { akan berubah } \\
\text { dan setelah di } \\
\text { hapus maka data } \\
\text { akan } \\
\text { menghilang dari } \\
\text { database }\end{array}$ & Sesuai \\
\hline 6. & $\begin{array}{l}\text { Menu } \\
\text { penggun } \\
\text { a }\end{array}$ & $\begin{array}{l}\text { Pada menu } \\
\text { pengguna } \\
\text { admin dapat } \\
\text { menambah, } \\
\text { merubah dan } \\
\text { menghapus } \\
\text { pengguna }\end{array}$ & $\begin{array}{l}\text { Setelah } \\
\text { pengguna di } \\
\text { tambah maka } \\
\text { data akan masuk } \\
\text { database, setelah } \\
\text { diubah maka } \\
\text { data pengguna } \\
\text { akan berubah } \\
\text { dan setelah di } \\
\text { hapus maka data } \\
\text { akan } \\
\text { menghilang dari } \\
\text { database }\end{array}$ & Sesuai \\
\hline 7. & $\begin{array}{l}\text { Menu } \\
\text { berita }\end{array}$ & $\begin{array}{l}\text { Pada menu } \\
\text { berita admin } \\
\text { dapat } \\
\text { menambah, } \\
\text { merubah dan } \\
\text { menghapus } \\
\text { berita }\end{array}$ & $\begin{array}{l}\text { Setelah berita di } \\
\text { tambah maka } \\
\text { data akan masuk } \\
\text { database, setelah } \\
\text { diubah maka } \\
\text { data berita akan } \\
\text { berubah dan } \\
\text { setelah di hapus } \\
\text { maka data akan } \\
\text { menghilang dari } \\
\text { database. dan } \\
\text { jika status berita } \\
\text { publish maka } \\
\text { berita akan } \\
\text { muncul di } \\
\text { halaman utama } \\
\text { website }\end{array}$ & Sesuai \\
\hline 8. & $\begin{array}{l}\text { Menu } \\
\text { USM }\end{array}$ & $\begin{array}{l}\text { Pada menu } \\
\text { usm admin } \\
\text { dapat } \\
\text { menambah, } \\
\text { merubah dan } \\
\text { menghapus } \\
\text { jadwal USM }\end{array}$ & $\begin{array}{l}\text { Setelah jadwal } \\
\text { USM di tambah } \\
\text { maka data akan } \\
\text { masuk database, } \\
\text { setelah diubah } \\
\text { maka data } \\
\text { jadwal USM } \\
\text { akan berubah } \\
\text { dan setelah di } \\
\text { hapus maka data } \\
\text { akan } \\
\text { menghilang dari } \\
\text { database. dan } \\
\text { jadwal USM } \\
\text { akan muncul di } \\
\text { dalam kartu } \\
\text { ujian }\end{array}$ & Sesuai \\
\hline
\end{tabular}


p-ISSN : 2640-7363

e-ISSN : 2614-6606

\begin{tabular}{|c|c|c|c|c|}
\hline 9. & $\begin{array}{l}\text { Menu } \\
\text { dasbor }\end{array}$ & $\begin{array}{l}\text { Menu dasbor } \\
\text { akan } \\
\text { menampilkan } \\
\text { informasi } \\
\text { statistik } \\
\text { pendaftar }\end{array}$ & $\begin{array}{l}\text { Jika menu } \\
\text { dasbor di klik } \\
\text { maka akan } \\
\text { tampil informasi } \\
\text { statistik } \\
\text { pendaftar sesuai } \\
\text { periode } \\
\text { penerimaan } \\
\text { siswa baru } \\
\text { berlangsung }\end{array}$ & sesuai \\
\hline 10. & $\begin{array}{l}\text { Menu } \\
\text { verifikas } \\
\text { i }\end{array}$ & $\begin{array}{l}\text { Menu } \\
\text { verifikasi } \\
\text { menampilkan } \\
\text { calon siswa } \\
\text { yang baru } \\
\text { mendaftar }\end{array}$ & $\begin{array}{l}\text { Menu verifikasi } \\
\text { bisa } \\
\text { memverifikasi } \\
\text { calon siswa baru } \\
\text { untuk } \\
\text { dimasukan ke } \\
\text { menu accept } \\
\text { test, } \\
\text { menampilkan } \\
\text { berkas yang } \\
\text { sudah di upload } \\
\text { calon siswa, } \\
\text { menampilkan } \\
\text { chat dan jumlah } \\
\text { chat dengan } \\
\text { caon siswa, } \\
\text { menampilkan } \\
\text { detail data siswa } \\
\text { saat d klik } \\
\text { tombol detail } \\
\end{array}$ & sesuai \\
\hline 11. & $\begin{array}{l}\text { Menu } \\
\text { accept } \\
\text { test }\end{array}$ & $\begin{array}{l}\text { Menu accept } \\
\text { test } \\
\text { menampilkan } \\
\text { calon siswa } \\
\text { yang baru } \\
\text { yang sudah di } \\
\text { verifikasi }\end{array}$ & $\begin{array}{l}\text { Menu accept test } \\
\text { bisa meluluskan } \\
\text { calon siswa dan } \\
\text { memasukanya } \\
\text { ke menu calon } \\
\text { siswa, } \\
\text { menampilkan } \\
\text { berkas yang } \\
\text { sudah di upload } \\
\text { calon siswa, } \\
\text { menggenerate } \\
\text { sebuah no ujian } \\
\text { yang akan } \\
\text { digunakan untuk } \\
\text { ujian, } \\
\text { menampilkan } \\
\text { kartu ujian } \\
\text { sesuai tombol } \\
\text { dengan nama } \\
\text { yang dipilih, dan } \\
\text { mengembalikan } \\
\text { status verifikasi } \\
\text { ke menu } \\
\text { verifikasi }\end{array}$ & sesuai \\
\hline
\end{tabular}

\begin{tabular}{|l|l|l|l|l|}
\hline 12. & $\begin{array}{l}\text { Menu } \\
\text { calon } \\
\text { siswa }\end{array}$ & $\begin{array}{l}\text { Menu calon } \\
\text { siswa } \\
\text { menampilkan } \\
\text { calon siswa } \\
\text { yang sudah } \\
\text { diterima atau } \\
\text { lulus untuk } \\
\text { masuk } \\
\text { sekolah }\end{array}$ & $\begin{array}{l}\text { Menu calon } \\
\text { siswa bisa } \\
\text { mengembalikan } \\
\text { calon siswa ke } \\
\text { menu accept test }\end{array}$ & \\
& & & \\
& & & \\
& & & \\
\end{tabular}

4. Pengujian Menu Panitia

Pada pengujian menu panitia sama saja fungsi yang digunakan dengan menu admin, hanya saja pada menu panitia hanya bisa mengakses menu verfikasi, accept test, calon siswa dan USM.

\section{KesimpUlan}

Pengembangan sistem informasi penerimaan peserta didik baru berbasis web ini merupakan solusi yang tepat bagi SMK Al-Halim Garut. Dari proses dan hasil penelitian ini, peneliti dapat mengambil kesimpulan :

1. Penelitian ini menghasilkan sistem informasi yang digunakan untuk mempermudah dalam pengelolaan pendaftaran peserta didik baru diantaranya dapat melakukan pendaftaran, pendataan dan menyeleksi calon siswa baru. Dimana tahapan pengembangan sistem informasi penerimaan peserta didik baru berbasi web yaitu : Pertama, Analisis. Kedua, Design. Ketiga, Pembuatan kode programan. Keempat merupakan tahapan terakhir yaitu pengujian dengan menggunkan black-box, yang berfungsi untuk memastikan bahwa semua bagian sudah di uji. Pengujian dalam sistem yaitu dari aspek fungsional seperti tujuan awal peneliti, serta untuk meminimalisir kesalahan (error) dan memastikan sistem yang dihasilkan sesuai dengan tujuan peneliti.

2. Dengan adanya sistem yang sudah dikembangkan, calon siswa dapat mendaftarkan diri secara online serta dapat melihat informasi yang berkaitan dengan penerimaan peserta didik baru.

3. Dengan adanya sistem informasi penerimaan peserta didik baru berbasis web ini dapat mencegah keterlambatan arus informasi dimana hal itu dapat dicegah karena pengolahan data dan pencarian data sudah terkomputerisasi sehingga informasi yang dihasilkan menjadi berkualitas.

\section{UCAPAN TERIMA KASIH}

Terima kasih kepada seluruh pihak yang telah bimbingan dan dukungan dalam proses pengembangan sistem informasi di SMK Al-Halim Garut. Semoga artikel ini dapat bermanfaat khusunya untuk pihak sekolah dalam meningkatan proses penerimaan peserta didik baru.

\section{DAFTAR PUSTAKA}


p-ISSN : 2640-7363

e-ISSN : 2614-6606

[1] C. Suhendar, "Rancang Bangun Sistem Informasi Penerimaan Siswa Baru Berbasis Web (Studi Kasus Pada SMK Ciledug Al-Musaddadiyah Garut)," J. STT-Garut All Right Reserv., vol. 1, no. (12) 1-8, ISSN Garut)," J. STT-Garut All Right Reserv., vol.
2302-7339., pp. 1-8, ISSN : 2302-7339, 2015.

[2] I. . Prabowo, "Sistem Informasi Penerimaan Peserta Didik Baru SMA I. Prabowo, "Sistem Informasi Penerimaan Peserta Didik Baru SMA
Negeri 1 Ngemplak Kabupaten Boyolali," J. Ilm. SINUS, no. 65-82, p. ISSN : $1693-1173 ., 2015$

[3] J. Hartono, Analisa dan Desain Sistem Informasi. Yogyakarta, 1990

[4] Witarto, "Memahami Sistem Informasi". Studi Dalam: Pendekatan Praktis Rekayasa Sistem Informasi Melalui Kasus-kasus Sistem Informasi di Sekitar Kita. Edisi Petana. Bandung. Informatika, 2004.

[5] X. B. Palilingan, Kenneth Y. R. Alicia A. E. Sinsuw, ST, MT and M. N Najoan, ST, "Registrasi Calon Siswa Baru Berbasis Mobile Android d Sekolah Menengah Atas Negeri 9 Manado," E-journal Tek. Elektro dan Komputer. ISSN 2301-8402., 2014.

[6] Jaelani, "Definisi Penerimaan Siswa Baru." Yogyakarta: Andi Offset,

[7] A.S Rosa dan M. Shalahuddin., Rekayasa Perangkat Lunak Terstruktur dan Berorientasi Objek. Informatika. Bandung, 2014.

[8] Al-Bahra, Analisis dan Desain Sistem Informasi. Yogyakarta, Graha llmu., 2005. 
p-ISSN : 2640-7363

e-ISSN : 2614-6606 